\title{
The overarching role of international marketing: Relevance and centrality in research and practice
}

\author{
Saeed Samiee ${ }^{1}$, \\ Constantine S. Katsikeas ${ }^{2}$ and \\ G. Tomas M. Hult ${ }^{3}$ \\ ${ }^{1}$ Collins College of Business, The University of \\ Tulsa, Tulsa, OK, USA; ${ }^{2}$ Leeds University Business \\ School, University of Leeds, Leeds, UK; ${ }^{3}$ Broad \\ College of Business, Michigan State University, \\ East Lansing, MI, USA \\ Correspondence: \\ S Samiee, Collins College of Business, The \\ University of Tulsa, Tulsa, OK, USA. \\ e-mail: samiee@utulsa.edu
}

\begin{abstract}
Classic business literature asserts the central role of marketing as foundational to the existence of organizations, and further notes that marketing must permeate all areas of a business enterprise. Leveraging this premise, we examine marketing scholars' contributions to the international business (IB) literature - specifically notable works in exporting and market entry. Despite the overarching role of marketing in business, our systematic examination of published works in JIBS identified only 11 marketing contributions among the top 100 most frequently cited publications. More recent Web of Science data for the most cited contributions since 2015 demonstrate a decline in the number of international marketing (IM) and IB-related contributions by marketing scholars. Our goal in this editorial is to re-emphasize marketing's critical importance and centrality in IB research, especially with reference to its dominant role in such areas as exporting and market entry decisions, customer acquisition, and relationship management. This special issue is intended to highlight IM and to motivate more contributions by IM scholars, as well as to call for greater integration of marketing thought in IB research.
\end{abstract}

Journal of International Business Studies (2021) 52, |429-| 444.

https://doi.org/ I 0.1057/s4 I 267-021 -00433-2

Keywords: international marketing-business; central role of marketing; market entry; exporting; relationship management; firm performance

\section{INTRODUCTION}

Marketing is the raison d'etre and the force that drives organizations. Among the many axioms advanced by Peter Drucker, the father of modern management, are that the purpose of a business is "to create customers", and that an organization has only two functions: one role relates to marketing (i.e., innovation) and the other is marketing (Drucker, 1954, p. 37; Trout, 2006; Webster, 2009). Drucker further observed that only innovation and marketing produce results (i.e., revenue streams); the rest are costs (Cohen, 2013). Product innovation is a key marketing strategy component and an important means of creating and keeping customers, and, hence, a central element of a successful competitive strategy. This marketing-based view is also shared by other management thought leaders. Ted Levitt (2006, p. 129), for example, notes that "the
Received: 13 December 2020

Revised: 19 March 2021

Accepted: 29 March 2021

Online publication date: 18 May 2021 
entire corporation must be viewed as a customercreating and customer-satisfying organism."

The "marketing-based" position held by seasoned management opinion leaders underscores the "overarching" role and centrality of marketing as a philosophy that should drive virtually all organizations. In fact, McKenna (1991) takes this notion even further by claiming “...successful companies are becoming market driven, adapting their products to fit their customers' strategies" (p. 66). Adopting market orientation and becoming a market-driven organization, in turn, require marketing to "permeate" all aspects of organizational decisionmaking, inclusive of international business activities, before a product is produced or externally sourced. Parenthetically, since marketing represents the interface of all businesses with their customers, it should be expected to play a central role in published academic works in business, including international business (IB) - the focus of attention in this editorial.

Many studies have examined research themes covered in IB journals. One such effort surveyed academic publications in the six leading IB-related journals, and identified and classified 112 articles with at least 20 citations each for the 1996-2006 period (Griffith, Cavusgil, \& Xu, 2008). Collectively, with over $22 \%$ of the most-cited publications, marketing was identified as having the largest number of publications. ${ }^{1}$ In keeping with business thought leaders' position on the purpose of an enterprise, one would expect a higher proportion of (1) internationally oriented marketing topics and/or (2) published works on other topics, such as IB, that actively include marketing in some meaningful way. Surprisingly, much of the published research in IB excludes marketing considerations. As an example, in examining foreign market entry and expansion modes [e.g., foreign direct investment (FDI)], the ultimate goal beyond the theoretical lens in use, efficiencies, drivers, order of market entry, and resultant models and theories - is to gain or create new customers and/or better serve current customers in markets worldwide. Such an approach constitutes a marketing-centric view of FDI.

The IB literature has demonstrated that firms engaging in FDI invest more in research and development (R\&D) and innovation (e.g., Anand \& Kogut, 1997); however, the IB literature is not explicit about why firms invest in innovation in the first place. $^{2}$ A marketing-centric view (e.g., Ellis, 2000; Knight \& Cavusgil, 2004; Leonidou \&
Katsikeas, 1996) does not imply a necessity to include marketing in every (e.g., market entry) project. Rather, it consists of a researcher mindset that conceives of and fine-tunes research projects in light of the ultimate purpose of an organization (per Drucker, Levitt, and McKenna) when marketing is not an explicit aspect of the study. The business worldview from within the marketing discipline is that marketing permeates the entire organization (including innovation). IB scholars recognize the integrated nature of marketing across various firm activities in specific sectors (e.g., in the services industry per Rugman \& Verbeke, 2008, p. 409), however, creating and serving customers necessitate the broadening of this perspective across all industries, as predicated in marketing. Stated differently, framing marketing as a single value chain function, or adopting a strictly downstream view of it inhibits richer and more meaningful customer-centric, as well as increasingly more realistic conceptualizations of critical activities and decisions in IB (cf. Takeuchi \& Porter, 1986). Among other downsides, the narrow conceptualization of marketing functions as downstream activities in the value chain undermines marketing's true role and influence in shaping strategy formulation. Global strategy decisions envisioned and designed by the C-suite inherently involve a very significant level of marketing content, without which a sound global strategy is not possible.

Concurrently, Buckley (2002a) voices concern that international marketing (IM) has neglected the proximal issue of globalization in studies of IM strategy. This concern is in line with the broader criticism that IM has also largely abandoned strategy issues (Kotabe, 2001). Indeed, the marketing discipline can be criticized for failing to fully embrace the influences of international and global dimensions across the many critical strategy pillars inherently thought of as marketing's intellectual domain. An examination of research priorities published by the influential Marketing Science Institute (MSI) demonstrates the discipline's relative inactive posture in IM/IB. In all, the 2020-2022 MSI Research Priorities report includes four internationally oriented topics among 126 research questions listed. ${ }^{3}$ It is thus not too surprising that IM scholars have paid only scant attention to research opportunities at the intersection of IM strategy and globalization, which, in turn, has limited our understanding of the crucial role that marketing plays in establishing, developing, and sustaining 
effective business operations across markets worldwide. In parallel, we assert that investigations of globalization should also include marketing strategy considerations.

\section{IM CONTRIBUTIONS TO JIBS}

To develop a better understanding of the contributions of marketing scholarship to the IB literature and, more specifically, to the Journal of International Business Studies (JIBS), we examined all highly cited articles published in JIBS since the journal's inception. We rank-ordered all articles by their total citation frequencies using the Web of Science (WOS) database. We identified 11 marketing articles on topics generally considered to belong to the marketing domain among the top 100 most-cited JIBS publications (Table 1). ${ }^{4}$ We further observed that scholars with marketing ties have also made highly cited general IB contributions to the literature. Overall, it is evident that marketing scholars have made significant contributions in JIBS to the extant IM and IB knowledge. However, it is also apparent that the most highly cited IM publications in JIBS were published in the 1982-2002 period. This pattern raises a question about the relative impact of IM, as measured by WOS citation frequencies, in JIBS published works. We thus examined the most-cited JIBS publications since 2015 (Table 2). The data indicate that, in contrast to pre-2015, fewer marketing studies have been among the top 100 most-cited articles published in JIBS as of late. In addition, fewer contributions on broader IB topics are by authors with close marketing ties.

Despite the centrality and importance of marketing in business, the influence of IM scholars and IM publications in the broader IB discipline via the field's leading journal has been on the decline. The marketing theme of this special issue of JIBS builds on business and management thought leaders' (e.g., Drucker, Levitt) view regarding the purpose of a business enterprise; that is, we start with the premise of the critical importance of marketing to all facets of business and leverage broad-based agreement about the declining role of marketing in IB research as well as broader IB contributions by marketing scholars in JIBS. Our overarching objective in this issue is to motivate relevant and rigorous research that advances IM and, in turn, IB thought on an ongoing basis, beyond the confines of this special issue. If one subscribes to Drucker's vision about the purpose of a business, then IM should be better integrated into and represented within IB publications, notably within $J I B S$, the leading and most highly cited journal in IB. To this end, our goals in this essay are to (1) highlight the role of IM within IB, (2) detail the many critical roles of marketing in today's business enterprise, and (3) introduce the marketing contributions in this special issue.

\section{THE ROLE OF IM WITHIN IB OVER TIME}

Beyond Drucker's view of the purpose of a business, IB at its core is inherently intertwined with marketing. For centuries, individuals and firms have sought to expand sales through exporting, which constitutes the most common foreign market entry and international expansion mode; for many firms, therefore, export marketing has defined IB. Indeed, all exporting is strictly rooted in marketing (see, for example, Anderson \& Gatignon, 1986). ${ }^{5}$ This view is implied in the broader perspective of export development, which emphasizes internal and external triggers to exporting (cf. Cavusgil \& Nevin, 1980; Wiedersheim-Paul, Welch, \& Olson, 1978), both of which are export marketing centered. Some scholars view all international market entry forms as essentially marketing driven (e.g., Douglas \& Craig, 1989). Indeed, many early contributors to foreign market entry and the export development process are closely associated with the marketing discipline (e.g., Bilkey \& Tesar, 1977; Cavusgil, 1980; Czinkota, \& Johnston, 1981; Katsikeas, 1996; Samiee \& Walters, 1991). Over time, some firms continue to reap the benefits of increased sales and profits via export marketing, whereas others, recognizing the broader and longer-term potential of global markets, have sought to establish different forms of engagement in markets abroad. For example, international leasing and licensing (i.e., limited-term rental contract of an asset) as means of foreign market entry or expansion constitute marketing activities, but they are often viewed as activities related to, for example, market expansion and operational strategy (e.g., Contractor, 1985; Ricks \& Samiee, 1974). It may be that the role and critical importance of IM is widely recognized by IB scholars. However, making marketing's presence more explicit in IB research can result in framing issues such that corresponding research findings will yield greater marketplace and marketing relevance, in line with Drucker's and Levitt's views on the purpose of business. In short, regardless of entry mode or a firm's structural configuration, market 
Table 1 Most-cited marketing contributions in JIBS and works by authors with marketing ties.

\begin{tabular}{|c|c|c|c|c|}
\hline $\begin{array}{l}J I B S \\
\text { rank }\end{array}$ & Author(s) & Title & $\begin{array}{l}\text { WOS } \\
\text { citations }\end{array}$ & $\begin{array}{l}\text { Citations } \\
\text { per year }\end{array}$ \\
\hline \multicolumn{5}{|c|}{ Marketing contributions } \\
\hline 20 & Bilkey and Nes (1982) & Country of origin effects on products evaluations & 674 & 17.74 \\
\hline 49 & $\begin{array}{l}\text { Steenkamp, Batra, and Alden } \\
\text { (2003) }\end{array}$ & How perceived brand globalness creates brand value & 457 & 26.88 \\
\hline 50 & Roth and Romeo (1992) & $\begin{array}{l}\text { Matching product category and country image perceptions: } \\
\text { Framework for managing country-of-origin effects }\end{array}$ & 457 & 16.32 \\
\hline $59^{a}$ & Bonaccorsi (1992) & On the relationship between firm size and export intensity & 441 & 15.75 \\
\hline 67 & Peterson and Jolibert (1995) & A meta-analysis of country-of-origin effects & 402 & 16.08 \\
\hline 68 & Erramilli (1991) & The experience factor in foreign-market entry behavior of service firms & 401 & 13.83 \\
\hline 74 & $\begin{array}{l}\text { Aulakh, Kotabe, and Sahay } \\
\text { (1996) }\end{array}$ & $\begin{array}{l}\text { Trust and performance in cross-border marketing partnerships: A } \\
\text { behavioral approach }\end{array}$ & 385 & 16.04 \\
\hline $77^{\mathrm{a}}$ & $\begin{array}{l}\text { Leonidou and Katsikeas } \\
\text { (1996) }\end{array}$ & $\begin{array}{l}\text { The export development process: An integrative review of empirical } \\
\text { models }\end{array}$ & 376 & 15.67 \\
\hline 84 & Dyer and Chu (2000) & $\begin{array}{l}\text { The determinants of trust in supplier-automaker relationships in the US, } \\
\text { Japan, and Korea }\end{array}$ & 355 & 17.75 \\
\hline 86 & $\begin{array}{l}\text { Kotabe, Srinivasan, and } \\
\text { Aulakh (2002) }\end{array}$ & $\begin{array}{l}\text { Multinationality and firm performance: The moderating role of R\&D } \\
\text { and marketing capabilities }\end{array}$ & 350 & 19.44 \\
\hline 91 & Han and Terpstra (1988) & Country of origin effects for uni-national and bi-national products & 344 & 10.75 \\
\hline \multicolumn{5}{|c|}{ IB contributions by authors with marketing ties } \\
\hline 10 & Knight and Cavusgil (2004) & Innovation, organizational capabilities, and the born-global firm & 1134 & 70.88 \\
\hline 14 & $\begin{array}{l}\text { Anderson and Gatignon } \\
\text { (1986) }\end{array}$ & Modes of market entry: A transaction cost analysis and propositions & 1000 & 29.41 \\
\hline 18 & $\begin{array}{l}\text { Eriksson, Johanson, } \\
\text { Majkgård, and Sharma } \\
\text { (1997) }\end{array}$ & Experiential knowledge and cost in the internationalization process & 724 & 31.48 \\
\hline 38 & Coviello (2006) & The network dynamics of international new ventures & 514 & 36.71 \\
\hline 39 & $\begin{array}{l}\text { Tihanyi, Griffith, and Russell } \\
\text { (2005) }\end{array}$ & $\begin{array}{l}\text { The effect of cultural distance on entry mode choice, international } \\
\text { diversification, and MNE performance: A meta-analysis }\end{array}$ & 513 & 34.20 \\
\hline 41 & Jones and Coviello (2005) & $\begin{array}{l}\text { Internationalisation: Conceptualising an entrepreneurial process of } \\
\text { behaviour in time }\end{array}$ & 503 & 33.53 \\
\hline 45 & Mullen (1995) & Diagnosing measurement equivalence in cross-national research & 483 & 19.32 \\
\hline 83 & Dow and Karunaratna (2006) & $\begin{array}{l}\text { Developing a multidimensional instrument to measure psychic distance } \\
\text { stimuli }\end{array}$ & 360 & 25.71 \\
\hline 93 & Child and Tse (2001) & China's transition and its implications for international business & 341 & 17.95 \\
\hline 96 & $\begin{array}{l}\text { Lovett, Simmons, and Kali } \\
\text { (1999) }\end{array}$ & Guanxi versus the market: Ethics and efficiency & 332 & 15.81 \\
\hline 98 & Ellis (2000) & Social ties and foreign market entry & 325 & 16.25 \\
\hline
\end{tabular}

Based on all available data (2,398 articles) published in JIBS through the WOS database.

a Exporting articles classified as marketing-related.

expansion and increased sales via (in)direct marketing internationally is central to IB. Such a view highlights the centrality and critical role of IM activities, while emphasizing the significance of IM contributions to the broader IB field.

Interest in and focus on scholarly research in IM began to intensify during the 1980s, and empirical investigations of IM problems and challenges facing firms have received heightened research attention for decades. Initial scholarly research in IM was limited, though there is noteworthy work on export market entry triggers as well as motivations and explanations for internationalization decisions (Ford \& Leonidou, 2013). Since this early research, IM scholars have amassed a growing, multifaceted, and well-developed body of knowledge. Despite these advances, however, the growing importance and relevance of IM remains underappreciated and understudied (Day, 1996). As an unfortunate outcome of this, IM topics in the top IB journals are sparse (cf. Griffith et al., 2008), and a current survey of several leading marketing and IB journals reveals a relative paucity of scholarly work on IM issues. ${ }^{6}$ Given IM's centrality to all enterprises, the primary 
Table 2 Most-cited marketing contributions in JIBS and works by authors with marketing ties (2015-2020).

\begin{tabular}{|c|c|c|c|c|}
\hline $\begin{array}{l}\text { JIBS } \\
\text { rank }\end{array}$ & Author(s) & Title & $\begin{array}{l}\text { WOS } \\
\text { citations }\end{array}$ & $\begin{array}{l}\text { Citations } \\
\text { per year }\end{array}$ \\
\hline \multicolumn{5}{|c|}{ Marketing contributions } \\
\hline 31 & Sharma (2015) & $\begin{array}{l}\text { Consumer ethnocentrism: Reconceptualization and cross-cultural } \\
\text { validation }\end{array}$ & 52 & 10.40 \\
\hline 39 & $\begin{array}{l}\text { Harmeling, Magnusson, } \\
\text { and Singh (2015) }\end{array}$ & Beyond anger: A deeper look at consumer animosity & 45 & 9.00 \\
\hline $71^{\mathrm{a}}$ & Xie and Li (2018) & $\begin{array}{l}\text { Exporting and innovating among emerging market firms: The } \\
\text { moderating role of institutional development }\end{array}$ & 27 & 13.50 \\
\hline \multicolumn{5}{|c|}{ IB contributions by authors with marketing ties } \\
\hline 1 & Cavusgil and Knight (2015) & $\begin{array}{l}\text { The born global firm: An entrepreneurial and capabilities perspective } \\
\text { on early and rapid internationalization }\end{array}$ & 239 & 47.80 \\
\hline 5 & Coviello (2015) & Re-thinking research on born globals & 120 & 24.00 \\
\hline
\end{tabular}

Based on 413 articles published in JIBS since 2015 through the WOS database.

${ }^{a}$ Exporting articles classified as marketing-related.

purpose of this special issue is to reinforce IM's broad-based importance, with a particular focus on IM in the broader IB context.

\section{RESEARCH IN IM}

A recent survey of the IM literature published in the top six IB/IM journals during the 1995-2015 period identified 1,722 published works (Leonidou, Katsikeas, Samiee, \& Aykol, 2017). The knowledge structure on which this body of scholarly work indicates that many of the developments in IM thought are driven by 14 key knowledge nodes identified in Samiee and Chabowski (2012). ${ }^{7}$ It is evident from the results of the investigation by Samiee and Chabowski (2012) that, in terms of knowledge base, IM has much in common with IB. A relatively high proportion (approximately 40\%) of key sources used in IM research are also commonly cited in IB research, including Hofstede (1980, 1991, 2001), Porter $(1980,1985,1990)$, Williamson (1975, 1985), Buckley and Casson (1976), Bartlett and Ghoshal (1989), Nelson and Winter (1982), Penrose (1959), and Pfeffer and Salancik (1978). Of the 26 most influential works in IM, serving as foundational knowledge for the 2004-2008 period, the majority (18) were published in outlets not specifically designated as marketingrelated (Samiee \& Chabowski, 2012), thus demonstrating IM's shared knowledge and close relationship to IB. Key IM knowledge nodes serving as the foundation of IM scholarship during this period appear in Table 3.

IM research has evolved across numerous themes, with some areas receiving disproportionate scholarly attention over time (Leonidou et al., 2017). Foreign market entry and export marketing are among the oldest topics of interest for IM researchers, and these remain relevant and important. Collectively, origin-related research topics likely constitute the most popular IM theme among IM researchers and potentially the most researched area, with hundreds of publications (e.g., Kotabe, 2001; Papadopoulos, el Banna, Murphy, \& RojasMéndez, 2011; Samiee \& Chabowski, 2021). ${ }^{8}$ Origin-related research - or more specifically, the country-of-origin line of research within IM - can be traced back broadly to Dichter (1962) and, more specifically, to Schooler (1965). Although the concept was applied strictly to customer product choice, it can and has been applied to other facets of IB (e.g., liability of foreignness). Beyond marketing, explicit recognition of business problems associated with nonlocal origins of firms began to emerge in the IB literature in the 1970s. For example, Buckley and Casson (1976) refer to the political problems of "foreignness," and Boddewyn and Hansen (1977, p. 550) note that "American companies were faced with handicaps due to their foreignness." Although IB challenges related to nonlocal origins of products and firms seem intuitive, international marketers' close proximity to markets and customers afforded them the opportunity to recognize the issue much earlier than appears to have been the case in the broader IB discipline. We highlight this issue to point to how IM and IB can and should leverage each other for a more comprehensive analysis and rapid advancement of the field. 
Table 3 Key knowledge nodes within the IM body of knowledge (2004-2008).

\begin{tabular}{|c|c|}
\hline Key IM knowledge nodes & Knowledge groups ${ }^{a}$ \\
\hline \multirow[t]{2}{*}{ The MNC and competitive advantage } & Buckley and Casson (1976) \\
\hline & Porter (1990) \\
\hline \multirow[t]{2}{*}{ Cultural values } & Hofstede (1980) \\
\hline & Hofstede (2001) \\
\hline \multirow[t]{2}{*}{ Market entry and cultural effects } & Hofstede (1980) \\
\hline & Kogut and Singh (1988) \\
\hline \multirow{2}{*}{ Internationalization and cultural effects } & Johanson and Vahlne (1977) \\
\hline & Kogut and Singh (1988) \\
\hline \multirow[t]{3}{*}{ Relationship marketing } & Anderson and Narus (1990) \\
\hline & Ganesan (1994) \\
\hline & Morgan and Hunt (1994) \\
\hline \multirow[t]{3}{*}{ Market orientation } & Jaworski and Kohli (1993) \\
\hline & Kohli and Jaworski (1990) \\
\hline & Narver and Slater (1990) \\
\hline \multirow[t]{2}{*}{ Market-oriented capabilities } & Day (1994) \\
\hline & Jaworski and Kohli (1993) \\
\hline \multirow[t]{2}{*}{ Resource-based competitive advantage } & Porter (1980) \\
\hline & Wernerfelt (1984) \\
\hline \multirow[t]{2}{*}{ Resource-based view } & Barney (1991) \\
\hline & Wernerfelt (1984) \\
\hline \multirow{2}{*}{ Dynamic capabilities and competitive advantage } & Barney (1991) \\
\hline & Teece, Pisano, and Shuen (1997) \\
\hline \multirow[t]{2}{*}{ Combinative capabilities and organizational learning } & Kogut and Zander (1992) \\
\hline & March (1991) \\
\hline \multirow[t]{2}{*}{ Economic change and absorptive capacity } & Cohen and Levinthal (1990) \\
\hline & Nelson and Winter (1982) \\
\hline \multirow[t]{2}{*}{ Theories of the firm and economic change } & Nelson and Winter (1982) \\
\hline & Penrose (1959) \\
\hline
\end{tabular}

Adapted from Samiee and Chabowski (2012).

a Underlying publications defining IM knowledge groups based on cocitations data of the most influential IM publications for the 2004-2008 period.

\section{RESEARCH OPPORTUNITIES GOING FORWARD}

Much of the intellectual capital in IM works has been devoted to various aspects of buyer behavior (Kotabe, 2001; Leonidou et al., 2017). This trend is not surprising given that, in general, a large majority of MSI research priorities (2020) are focused on customer-related issues (including three of the four internationally oriented themes out of the 126 research questions posed). Among international themes, one research question pertains to gaining global perspectives on prioritizing customer value at all touchpoints during the omnichannel customer experience; another theme seeks to understand whether customer behavior is the same or different in emerging markets; and a third issue addresses ways in which firms might integrate consumer-focused strategies globally. A sharp focus on the buyer and, more specifically, the consumer and his/her behavior highlights an ongoing emphasis on behavioral issues within marketing at the expense of advancing other equally salient issues in need of development. As a result, some important IM research areas are not receiving sufficient scholarly attention. To this end, 25 years ago, Day (1996, p. 15) noted that "studies of cross-cultural differences in buyer behavior or the effect of country of origin do not suffice when the big issues needing answers are about global competitive interactions, global new product development and launch practices, sharing of market insights across borders, or the coordination and integration of multicountry operations." An overemphasis on the buyer behavior aspects of IM, frequently via experiments, has indeed curbed scholarly efforts to advance IM and the exploration of "big issues": for example, the short- and longterm effects of radical shifts in the external environment and competitive structures on various aspects of marketing strategy, notably, global supply chain management, innovation, and global product development activities, among others. In 
general, innovation can be related to and affect any facet of an enterprise's operations (e.g., processes). The key innovation concern within marketing has centered on product breakthroughs and service delivery, as well as how firms can adapt to a changing landscape often marked by disruptive technological developments. Nevertheless, studies of global innovation or R\&D can benefit from crossfertilization, with significant advances in this area within marketing.

Despite the decades-long practice of international outsourcing by firms, few IM researchers have explored this critical area (e.g., Kotabe \& Murray, 1990; Swamidass \& Kotabe, 1993). As a result, scant research is available within this important area to shed light on IM practices [e.g., innovate vs. import (buy) new products; make vs. buy] that can facilitate enhanced IM performance. To this end, a fourth research priority identified by MSI (2020) is the global supply chain impact of the pandemic (p. 11). Sourcing considerations, such as exporting and importing, are by nature customercentric and marketing-based. Nevertheless, much of the research in the area is conducted within other disciplines (Buckley, Doh, \& Benischke, 2017). The importance of a focus on the bigger picture, including the organization, human capital, capabilities, innovation, and metrics, has been stressed in marketing (Moorman \& Day, 2016). Behavioral components should continue to play important roles in advancing marketing (and IM); however, these topics need to be examined within the context of organizational priorities and not strictly limited to consumer-based studies.

Given the commonality of direct and indirect international involvement across firms and industries, a host of new and exciting challenges related to customers, suppliers, and relationship management are raised. Today's global marketplace is characterized by disruptive external forces, intense competition from a multitude of foreign and indigenous companies, and heterogeneous customer behavior shaped by differences across a range of host-market conditions, notably culture. Technological advances create marketplace opportunities and novel business models and segments (e.g., social media, collaborative consumption/ shared economy, product cocreation), while undermining long-established global brands, product/ service markets, and business patterns and processes on a global scale. For example, local and international ride-hailing services such as Ola and Uber competing with long established global car rental firms; collaboratively developed HD DVD losing the industry-wide format war to the technologically more advanced Blu-ray by Sony shortly after its debut which, in turn, lost popularity as the market shifted to streaming services; photorefractive keratectomy developed in the U.S. essentially undermined the Russian-born radial keratectomy; and MP3/FLAC and streaming services largely replaced tangible music CDs developed through an R\&D joint venture between Philips and Sony. Concurrently, new technologies are promoting new forms of interaction for businesses and customers that transcend national boundaries (e.g., social media; short message service-SMS; online reviews; using proprietary consumer data via artificial intelligence activated voice recognition to drive host-market demand, as is the case with Amazon's Alexa or Google Assistant). Concurrently, innovative breakthroughs and rapid dissemination of information have given rise to intellectual property theft on a global scale, undermining marketing strategies, global brands, and distribution network relationships and their management, while requiring all firms to canvass markets globally to identify potential abuses and to assert control over their intellectual property. ${ }^{9}$

Although the Internet and information technology (IT) continue to have a significant influence on customers and businesses (e.g., exporters, importers, concept-testing, global marketing strategy planning), a citations-based review of the IM literature revealed that IT-related topics did not constitute a knowledge base in IM (Samiee \& Chabowski, 2012). This finding was corroborated by Leonidou et al. (2017), who noted that less $4 \%$ of IM-related academic articles reviewed included various facets of Internet connectivity. In addition, a literature review of 29 academic journals addressing the Internet's impact on relational approaches to foreign market entry identified only 94 published articles, constituting approximately 3\% of all the articles reviewed (Watson, Weaven, Perkins, Sardana, \& Palmatier, 2018). IT has transformed how firms enter and manage markets globally to varying degrees in ways that are often not self-evident. In addition, IT's ubiquity and intangible nature make its detection and true impact on IM difficult, thus leading to a growing knowledge gap. The paucity of IT-motivated IM research uncovered by these reviews demonstrate the need to incorporate various facets of IT in more IM projects, including initial online export/import information gathering, marketing research, market entry and 
development, and export customer acquisition by both manufacturers and channel intermediaries. Furthermore, a research focus on cross-border e-commerce, especially as a means of internationalizing the scope of smaller firms' marketing, is underdeveloped. It is surprising that, while originrelated buyer behavior topics remain popular, almost no effort has been made to explore how origin affects choice in online and, in particular, international e-commerce contexts (e.g., Ulgado, 2002). Buckley (2002a) rightfully identified e-commerce as a frontier in IM research nearly two decades ago. Firms allocate significant amounts of financial resources to adopt promising technologies to improve their marketing performance, yet little research has been devoted to assessing the performance impact of digital tools (e.g., customer relationship management software) in terms of establishing new cross-border relationships or maintaining existing ones. Although IM has generally ignored such impactful areas of research as the influence of the Internet in global marketing, the IB literature, and more specifically international management, has also been shortsighted with respect to its limited pursuit of pertinent Internet-related research topics (e.g., international human resource management, global strategy development, management of global collaborative ventures and partnerships) (Chabowski \& Samiee, 2020).

Social media influence both the demand and the supply side of exchange. On the supply side, firms are engaging people by allowing them to participate in cocreation and product development processes. Enterprises are increasingly engaging the public in idea generation via social media (e.g., Dell IdeaStorm, LEGO World Builder), new product development, and start-up capital (e.g., Quirky, Kickstarter). The degree to which firms engage social media audiences internationally (including both global and local social media sites) for one or more aspects of cocreation, and the influence of such activity on multinational corporations' competitiveness across markets, remain unexplored. Examining the extent to which customers from around the world participate in knowledge development processes and help firms improve their existing products and/or create innovative ones also remains a fertile research area (Bayus, 2013; Prahalad \& Ramaswamy, 2004).

Equally important research issues on the demand side also warrant research attention. For example, customers located in distant parts of the world use social media, but the impact of such engagement, and the positive or negative ripple effect it creates in or across social networks with respect to local and global brands, has received insufficient research attention (McAlexander, Schouten, \& Koenig, 2002). Furthermore, the extent to which various customer segments rely on and ways in which they use social media across markets remain unexplored. This knowledge void, in turn, impacts the development of effective international cocreation strategies on the supply side. Relatedly, the global ubiquity of the Internet and social networks has made these media a major target for cybercriminals. Regular revelations of firm and customer data breaches are bound to have a consequential impact, not only on firm image and the customer engagement process, scope, and depth but also on demands for greater privacy and protection by customers and governments. Thus, IM research should explore the impact of, for example, crossnational privacy regulations on the efficacy of relationship development and management as well as online marketing processes.

Globalization has transformed the way business relationships are formed, managed, and evaluated, and customer engagement is likely to play a prominent role in business-to-business contexts. Business relationships are complex, interpersonal, and interdependent, and relationship marketing efforts can make a difference in promoting common goals and facilitating joint activities that create value for both partners; value that each company could not achieve outside the relationship or with other partners (Palmatier, 2008). In an international context, companies need to manage their cross-border relationships more skillfully to address geographic separation, cultural distance, administrative (e.g., currencies, legal jurisdictions) and economic (Katsikeas, Samiee, \& Theodosiou, 2006; Leonidou, Samiee, Aykol, \& Talias, 2014; Samiee, Chabowski, \& Hult, 2015) differences between local and foreign markets, and increased levels of risk and uncertainty inherent in international operations (Johanson \& Vahlne, 2009; Katsikeas, Skarmeas, \& Bello, 2009). How does the international environment affect the activities, strategies, structures, and decision-making processes of companies with respect to their business relationships? How can companies manage their overseas business relationships as value-bearing assets? Are cross-border business relationships part of a value-creating network that delivers superior value to the end customer? What is the role of 
international relationship building and management in overcoming the liability of foreignness? Likewise, the roles of overseas business partners (e.g., distributors, suppliers) in knowledge development, innovation, and goal achievement are relevant and important areas that require research attention.

The fit between IM strategy and international relationships also deserves ongoing research attention. How can companies ensure that their different suppliers and partners abroad are well-aligned with their IM strategy? Strategy standardization offers significant economies of scale in valueadding activities (e.g., R\&D, production, marketing), facilitates the development of a consistent corporate/brand image across countries, enhances coordination and control of international operations, and reduces operational and managerial complexity, whereas adaptation is based on the premise that variations between countries necessitate adjustment of the marketing strategy to the idiosyncrasies of each local market. The contingency approach suggests that the appropriateness of the selected IM strategy - typically positioned between the two standardization-adaptation extremes - should be evaluated based on its alignment, or fit, with dominant factors in the international environment, as fit facilitates enhanced performance outcomes (Katsikeas et al., 2006). Despite long-standing traditions in these areas, sensemaking in some overarching topics is needed. For example, the pursuit of a market orientation strategy demands sensitivity to local market conditions and IM strategy adaptation. Given the importance of market orientation for many firms, there is a need to better understand how market orientation influences IM strategy. On the one hand, market and customer orientation demand more localized or adapted IM strategies. On the other hand, a high degree of IM strategy standardization seemingly impedes a high degree of market orientation. How do firms reconcile their IM strategy and market orientation efforts? Moreover, how do customer relationships in particular and business relationships in general interact with the perennial issue of adaptation or standardization of IM strategy? Do overseas business relationships help the company determine which specific strategic elements are feasible or desirable to standardize or adapt? If so, under what conditions, and to what degree? To what extent is cocreation possible and appropriate under each IM strategy scenario?
In addition, the assessment of performance in international market operations is an issue that requires particular attention in the IM literature. The relevance and importance of IM resources, strategies, and actions is reflected in the extent to which these favorably influence firm performance outcomes achieved via international market operations and, in turn, contribute to organizational performance. However, there are a large number and wide diversity of IM performance measures employed in the literature, which makes the development of a coherent cumulative body of knowledge in the field particularly challenging (Katsikeas, Morgan, Leonidou, \& Hult, 2016). Scant attention has been given in IM as to how performance should be conceptualized and operationalized, and studies commonly do not provide a definition or any justification for the assessment of performance that is adopted and for the specific measures used in the context of foreign market operations (Katsikeas, Leonidou, \& Morgan, 2000; Leonidou, Katsikeas, \& Samiee, 2002). Given that performance is inherently a multidimensional construct, it is essential that IM researchers be selective in choosing specific performance dimensions, and justify their choice on the basis of some theorybased logic, conceptual framing, and/or for pragmatic reasons. Performance assessment in international market operations should be in line with the theoretical perspective(s) adopted in the study. For example, empirical research grounded in the resource-based view and/or the dynamic capabilities perspective, which underpins much of the strategy-related and competitive advantage work in IM, requires a competitor-centered assessment of performance outcomes; that is, individual performance aspects and items need to be assessed in relation to competition in the foreign market targeted by the firm's IM strategy (see Katsikeas et al., 2016).

\section{CONTRIBUTIONS TO THE SPECIAL ISSUE}

The call for papers for this special issue has been received with much enthusiasm, as demonstrated by the large number of submissions covering a wide range of IM topics. Accordingly, manuscripts accepted for inclusion in this issue represent the diversity of submissions, with each making a unique contribution to the IM body of knowledge. The first article focuses on the sharing economy (SE), which is a timely and important issue that influences business operations across industries 
worldwide. Kozlenkova, Lee, Xiang, and Palmatier's meta-analytic effort examines the effects of valuebased (i.e., utilitarian, social, hedonic, and sustainability value) and governance-based (i.e., trust) factors on SE participation and investigates their relative effectiveness under different global contingencies (i.e., economic/competitive, cultural, societal, technological, regulatory, and demographic factors). Based on 55 empirical articles, with 60 independent samples from 15 countries, representing 123 correlations across 26,377 customers during the 2009-2019 period, the findings suggest that hedonic value exerts the largest effect on SE participation, followed by trust and utilitarian value, while social value and sustainability have the smallest effects. The analysis reveals a complex pattern of global contingency effects that firms should consider when advancing their entry strategies, formulating governance mechanisms, and evaluating promising markets. Kozlenkova et al. integrate their key insights into three tenets, reflecting the most important and surprising findings. These tenets are grounded in the vitally important roles of inequality, the hierarchy of needs, and governance mechanisms that can serve as a platform for establishing an emerging perspective of global SE participation.

Marketing metrics represent another critically important topic that has received little research attention in IM or IB. Sound managerial decisions and marketing strategy are based on quantitative measures, including outcomes (Moorman \& Day, 2016). In their contribution to this special issue, Mintz, Currim, Steenkamp, and de Jong focus on metric use in marketing decisions across 16 countries, using a cultural perspective. The authors leverage a rich dataset containing more than 4,300 marketing decisions in more than 1,600 firms across 16 countries. Respondents chose from 24 general metrics pertinent to marketing (12) and financial (12) decisions, plus 6 metrics specific to each of 10 marketing mix decisions. The findings indicate that, for all markets combined, an average of 9 metrics are used per marketing decision. With nearly 12 metrics per decision, South Korean managers use the highest number of metrics, while Japanese managers use the fewest, with approximately 4 metrics per marketing decision. China and India, each with approximately 11 metrics, are close to Korea and are heavy users of marketing metrics, whereas France and the United States, with nearly 6 and 7, respectively, are moderate users of metrics in decision-making. Importantly, satisfaction, awareness, and return on investment are the three most commonly used metrics across markets. In addition, the study finds that metric use is affected by both firm and country culture.

Business-to-business (B2B) electronic platforms (e-platforms) play a critical role in helping exporting firms reach, serve, and penetrate foreign markets. However, the IB literature is unclear about how and under what conditions firms can use B2B e-platforms to boost their export performance outcomes. Drawing on signaling theory, Jean, Kim, Zhou, and Cavusgil propose and empirically test a model that investigates how exporters' e-platform use affects export sales performance by boosting foreign market contact (i.e., quotations from foreign buyers) and how the institutional environment and export growth strategies influence the e-platform use-foreign market contact link. Using survey and archival lagged data on a sample of 205 exporters that subscribe to Alibaba.com, the authors reveal that e-platform use enhances foreign buyer contact and, in turn, export sales performance. The findings also suggest that the positive impact of e-platform use among exporters is further boosted when they come from regions that have less-developed market intermediaries or under conditions of high institutional distance between the home and host countries. The study also demonstrates that the effect of e-platform use on a foreign buyer contact becomes weaker under conditions of high export market diversification or high product diversification.

Platform-based mobile payments have experienced significant growth worldwide in recent years, partly because they offer unique value for both customers and companies over other digital payment methods. Kumar, Nim, and Agarwal note, however, that patterns of such payment adoption grow differently across countries, with some emerging countries (e.g., China) outperforming developed ones. The authors propose a conceptual model of mobile payment adoption, and develop hypotheses using explanations from the literature on network effects and institutional theory. Based on data collected across 30 countries (17 developed and 13 emerging), the study confirms the existence of network effects and differential influences of perceived value, inertia, and cultural factors on the mobile payment adoption of innovators and imitators. The presence of significant heterogeneity both within and between countries regarding the adoption of mobile payments, which offers additional evidence of leapfrogging by emerging 
markets with regard to mass mobile payment use, has important implications for theory development and marketing management practice in IB.

Global brands and perceived brand globalness (PBG) research have received much scholarly attention in the IM literature (Aaker \& Joachimsthaler, 1999; Batra, Ramaswamy, Alden, Steenkamp, \& Ramachander, 2000; Steenkamp et al., 2003). Contributing to this growing literature, Mandler, Bartsch, and Han tap the potential aversion to globalization among consumers and examine sentiments with respect to branding as the basis for corporate decisions regarding the appropriateness of global branding. The authors leverage signaling theory to conduct two studies that (1) assess brand credibility on the basis of consumer PBG and perceived brand localness (PBL) across two countries (Germany and South Korea), and (2) examine the role of three moderators (perceived country of origin, category social signaling value, and category cultural grounding). The findings demonstrate that both PBG and PBL are positively associated with brand credibility across markets; a split-sample test offers a contrast between globalized and globalizing markets, and demonstrates a relationship between brand credibility and PBL in Germany but not in South Korea, where brand credibility is associated with PBG. The study reports the impact of brand origin on brand credibility and demonstrates that effect of PBL on brand credibility does not vary with the brand's origin in Germany, but the effect is stronger for domestic brands than for foreign brands in South Korea. The contrast between consumer perceptions in globalized and globalizing markets offers fruitful theoretical and managerial implications, while raising a series of consumer and IM strategy questions that have the potential to expand the boundaries of IM knowledge.

Origin-related research and animosity with reference to consumer perceptions, preferences, and choice have played major roles in the marketing literature (Klein, Ettenson, \& Morris, 1998; Lu, Heslop, Thomas, \& Kwan, 2016; Samiee, 1994; Verlegh \& Steenkamp, 1999). In line with this stream of IM research, Westjohn, Magnusson, Peng, and Jung contrast animosity's effect on product judgement versus willingness to buy. The first part of their contribution consists of a metaanalysis of 43 post-Klein et al. (1998) published works focusing on animosity, involving 18 nations, to address the inconsistencies reported in the literature. The authors follow this with an examination of the contextual role of culture on animosity effects using six experiments in the United States and China. They leverage three Hofstede dimensions (i.e., collectivism, long-term orientation, and power distance), measured at the individual level. The results indicate that collectivism and long-term orientation lessen the negative effects of animosity and support the position that animosity's effect on willingness to buy is stronger than it is on product judgments. The findings offer useful insights for managers regarding, among others, consumers' attitudes toward brands. Although the findings indicate that product judgements are not affected by animosity, the results indicate that product sales could be affected. In addition to demonstrating cross-cultural differences, the authors find that cultural values influence consumers' willingness to buy.

The establishment, development, and management of cross-border interorganizational exchange relationships has received considerable research attention in the IB literature (e.g., Bello \& Gilliland, 1997; Robson, Katsikeas, Schlegelmilch, \& Pramböck, 2019; Skarmeas, Katsikeas, \& Schlegelmilch, 2002). The starting point for Obadia and Robson's study is the inconsistent findings in the literature regarding the effects of cooperation on performance in exporter-importer relationships. The authors argue that the relationship of cooperation with performance in IB associations has an inverted U shape; at high levels, the performance impact of cooperation weakens greatly and becomes negative. They also find that the importer's specific investments mediate the link between cooperation and performance, which advances the idea that relational phenomena affect exporter performance only if they foster an importer's productive behaviors. The study also points to the role of interdependence in moderating the inverted U-shaped relationship between cooperation and the importer's specific investments. The findings reveal that a limited increase of interdependence enhances the impact of low to moderate levels of cooperation on the importer's specific investments.

\section{CONCLUDING REMARKS}

Overall, criticisms of IM scholarship (e.g., Buckley, 2002a; Douglas \& Craig, 1992; Kotabe, 2001) are generally well placed and to the point. Marketing and IM are pivotal to a firm's existence and should play overarching roles in charting firms' management and strategy. Yet IM has largely abandoned the "big picture" by focusing on microresearch and 
behavioral questions, notably, country-of-origin, and cross-cultural consumer behavior topics (Day, 1996; Kotabe, 2001; Leonidou et al., 2017).

Much work remains for IM scholars to advance the field by placing greater emphasis and effort on strategy-related topics and exploring macro-areas of business: for example, by bridging IM strategy with regard to market entry modes and globalization and addressing issues related to disruptive external change to global supply chains and e-commerce, among others. Indeed, Buckley's (2002b) position regarding the past successes of IB scholarship in exploring international market entry (the "big picture") may seem premature if one agrees that marketing, a central concern of which is the customer and the idiosyncrasies associated with the demand-side, is largely absent from much of this success. The relative absence of "marketing" in much of the market entry literature is a call for IB and IM scholars to leverage this critical aspect of firms' internationalization decisions. This view is consistent with Drucker's position that "Concern and responsibility for marketing must therefore permeate all areas of the enterprise" (Drucker, 1954, pp. 38-39). Additionally, the fact that IB and IM are close in their fundamentals, and that the IM knowledge structure significantly taps into management scholarship (Buckley, 2002a; Samiee \& Chabowski, 2012), further validates marketing's relevance and centrality in the broader international business thought. Consequently, the perceived proximity of these disciplines appears to be greater than one might expect. A major strength of IB has been its ability to embrace and integrate other business disciplines from which crucial research questions emerge (Peng, 2004). A more marketing- and customer-centric view of IB research is also in line with this position.

There appears to be ample research opportunity to adopt a marketing mindset in IB research and to explicitly introduce marketing considerations to achieve a marketing-based view of IB activities, most notably the macro-issues, including market entry mode choice, international expansion patterns, cross-border buyer-seller relationships, and strategic alliances. Although this special issue is primarily intended to inspire and broadly direct researchers' focus on developing IM projects that fill key knowledge gaps in IM thought, in keeping with Drucker's and Levitt's positions regarding the marketing purpose of all enterprises, we very much hope that this work offers pathways for general IB scholars to embrace, leverage, and contribute to IM knowledge.

\section{NOTES}

${ }^{1}$ The proportion of marketing articles reported by Griffith et al. (2008) is likely inflated, as two of the six journals surveyed are dedicated entirely to international marketing topics.

${ }^{2}$ This issue maybe exacerbated by the use of varying terminologies across disciplines; however, despite marketing's centrality in business, "marketing" and "consumer" or "customer" are rare terms in much IB research (cf. Anand \& Kogut, 1997; Hejazi, Tang, \& Wang, 2020).

${ }^{3} \mathrm{MSI}$ is a non-profit organization led by academic researchers, in collaborations with industry, aiming to address marketing issues faced by firms. Although we do not observe an ongoing internationally related research momentum in its current list of priorities, MSI has periodically addressed selective IM-related topics.

${ }^{4}$ We also calculated citation per year to account for the timing of the published works; however, as Tables 1 and 2 show, among the highly cited works, the most-cited set and the order of articles remain largely the same.

${ }^{5}$ This includes intracorporate export transactions involving parts and semifinished products. International firms frequently require subsidiaries to effectively compete in quality, price, and service with other suppliers, effectively marketing themselves as the premier supplier to the internal customer. Even if intrafirm export sales were guaranteed, as is the case in some firms, the final assembled product must still compete with other firms in every respect. In other words, the marketing function of intracorporate export transactions is merely pushed to the firm assembling and selling the final product.

${ }^{6}$ Several journals, led by Journal of International Marketing and International Marketing Review, are dedicated to publishing scholarly IM research.

${ }^{7}$ This is based on the spatial configuration generated by multidimensional scaling for works published in 34 scholarly journals (2,709 articles) in the 2004-2008 period. Other analyses (factor analysis and clustering) produced slightly fewer knowledge groups. 
${ }^{8}$ Estimates of the number of publications in this IM domain vary. For example, Samiee and Chabowski (2021) identify more than 482 country-oforigin publications listed in the Web of Science database, whereas Lu et al. (2016) estimate that the number of country-of-origin-related publications exceed 600.

\section{REFERENCES}

Aaker, D. A., \& Joachimsthaler, E. 1999. The lure of global branding. Harvard Business Review, 77: 137-146.

Anand, J., \& Kogut, B. 1997. Technological capabilities of countries, firm rivalry and direct investment in the United States. Journal of International Business Studies, 28(3): 445-466.

Anderson, E., \& Gatignon, H. 1986. Modes of foreign entry: A transaction cost analysis and propositions. Journal of International Business Studies, 17(3): 1-26.

Anderson, J. C., \& Narus, J. A. 1990. A model of distributor firm and manufacturer firm working partnerships. Journal of Marketing, 54(1): 42-58.

Aulakh, P. S., Kotabe, M., \& Sahay, A. 1996. Trust and performance in cross-border marketing partnerships: A behavioral approach. Journal of International Business Studies, 27(5): 1005-1032.

Barney, J. 1991. Firm resources and sustained competitive advantage. Journal of Management, 17(1): 99-120.

Bartlett, C. A., \& Ghoshal, S. 1989. Managing across borders: The transnational solution. Harvard Business School.

Batra, R., Ramaswamy, V., Alden, D. L., Steenkamp, J. B. E., \& Ramachander, S. 2000. Effects of brand local and nonlocal origin on consumer attitudes in developing countries. Journal of Consumer Psychology, 9(2): 83-95.

Bayus, B. L. 2013. Crowdsourcing new product ideas over time: An analysis of the Dell IdeaStorm community. Management Science, 59(1): 226-244.

Bello, D. C., \& Gilliland, D. I. 1997. The effects of output controls, process controls, and flexibility on export channel performance. Journal of Marketing, 61(1): 22-38.

Bilkey, W. J., \& Nes, E. 1982. Country-of-origin effects on product evaluations. Journal of International Business Studies, 13(1): 89-100.

Bilkey, W. J., \& Tesar, G. 1977. The export behavior of smallersized Wisconsin firms. Journal of International Business Studies, 8(1): 93-98.

Boddewyn, J. J., \& Hansen, D. M. 1977. American marketing in the European Common Market, 1963-1973. European Journal of Marketing, 11(7): 548-563.

Bonaccorsi, A. 1992. On the relationship between firm size and export intensity. Journal of International Business Studies, 23(4): 605-635.

Buckley, P. 2002a. International business versus international marketing. International Marketing Review, 19(1): 16-20.

Buckley, P. J. 2002b. Is the international business research agenda running out of steam? Journal of International Business Studies, 33(2): 365-373.

Buckley, P. J., \& Casson, M. 1976. The future of the multinational enterprise. New York: Holmes \& Meier.

Buckley, P. J., Doh, J. P., \& Benischke, M. H. 2017. Towards a renaissance in international business research? Big questions, grand challenges, and the future of IB scholarship. Journal of International Business Studies, 48(9): 1045-1064.

Cavusgil, S. T. 1980. On the internationalization process of firms. European Research, 8(November): 273-281.

Cavusgil, S. T., \& Knight, G. 2015. The born global firm: An entrepreneurial and capabilities perspective on early and rapid
${ }^{9}$ The International Chamber of Commerce estimates the global economic value of counterfeiting to reach US $\$ 2.3$ trillion by 2022 . https://iccwbo. org/media-wall/news-speeches/global-impactscounterfeiting-piracy-reach-us4-2-trillion-2022/.

internationalization. Journal of International Business Studies, 46(1): 3-16.

Cavusgil, S. T., \& Nevin, J. R. 1980. A conceptualization of the initial involvement in international marketing. Theoretical developments in marketing (pp. 68-71). Chichago: American Marketing Association.

Chabowski, B. R., \& Samiee, S. 2020. The Internet and the international management literature: Its development and intellectual foundation. Journal of International Management. https://doi.org/10.1016/j.intman.2020.100741.

Child, J., \& Tse, D. K. 2001. China's transition and its implications for international business. Journal of International Business Studies, 32(1): 5-21.

Cohen, W. A. 2013. Drucker on marketing: Lessons from the world's most influential business thinker. New York: McGrawHill.

Cohen, W. M., \& Levinthal, D. A. 1990. Absorptive capacity: A new perspective on learning and innovation. Administrative Science Quarterly, 35(1): 128-152.

Contractor, F. J. 1985. Licensing in international strategy: A guide for planning and negotiations. Quorom Books.

Coviello, N. E. 2006. The network dynamics of international new ventures. Journal of International Business Studies, 37(5): 713-731.

Coviello, N. 2015. Re-thinking research on born globals. Journal of International Business Studies, 46(1): 17-26.

Czinkota, M. R., \& Johnston, W. J. 1981. Segmenting US firms for export development. Journal of Business Research, 9(4): 353-365.

Day, G. S. 1994. The capabilities of market-driven organizations. Journal of Marketing, 58(4): 37-52.

Day, G. S. 1996. Using the past as a guide to the future: Reflections on the history of the Journal of Marketing. Journal of Marketing, 60(January): 14-16.

Dichter, E. 1962. The world customer. Harvard Business Review, 40(4): 113-122.

Douglas, S. P., \& Craig, C. S. 1989. Evolution of global marketing strategy: Scale, scope, and synergy. Columbia Journal of World Business, 24(3): 47-59.

Douglas, S. P., \& Craig, C. S. 1992. Advances in international marketing. International Journal of Research in Marketing, 9(4): 291-318.

Dow, D., \& Karunaratna, A. 2006. Developing a multidimensional instrument to measure psychic distance stimuli. Journal of International Business Studies, 37(5): 578-602.

Drucker, P. F. 1954. The practice of management. New York: Harper \& Brothers.

Dyer, J. H., \& Chu, W. 2000. The determinants of trust in supplier-automaker relationships in the US, Japan and Korea. Journal of International Business Studies, 31(2): 259-285.

Ellis, P. 2000. Social ties and foreign market entry. Journal of International Business Studies, 31(3): 443-469.

Eriksson, K., Johanson, J., Majkgård, A., \& Sharma, D. D. 1997. Experiential knowledge and cost in the internationalization process. Journal of International Business Studies, 28(2): 337-360. 
Erramilli, M. K. 1991. The experience factor in foreign market entry behavior of service firms. Journal of International Business Studies, 22(3): 479-501.

Ford, D., \& Leonidou, L. C. 2013. Research developments in international marketing. In S. J. Paliwoda (Ed.), New perspectives on international marketing: 3-32. Abingdon: Routledge.

Ganesan, S. 1994. Determinants of long-term orientation in buyer-seller relationships. Journal of Marketing, 58(2): 1-19.

Griffith, D. A., Cavusgil, S. T., \& Xu, S. 2008. Emerging themes in international business research. Journal of International Business Studies, 39(7): 1220-1235.

Han, C. M., \& Terpstra, V. 1988. Country-of-origin effects for uni-national and bi-national products. Journal of International Business Studies, 19(2): 235-255.

Harmeling, C. M., Magnusson, P., \& Singh, N. 2015. Beyond anger: A deeper look at consumer animosity. Journal of International Business Studies, 46(6): 676-693.

Hejazi, W., Tang, J., \& Wang, W. 2020. Selection, learning, and productivity at the firm level: Evidence from Canadian outward FDI. Journal of International Business Studies.. https://doi.org/10.1057/s41267-020-00343-9.

Hofstede, G. 1980. Culture's consequences: International differences in work-related values. Thousand Oak: Sage.

Hofstede, G. 1991. Cultures and organizations: Software of the mind. New York: McGraw-Hill.

Hofstede, G. 2001. Culture's consequences: Comparing values, behaviors, institutions, and organizations across nations. Thousand Oak: Sage.

Jaworski, B. J., \& Kohli, A. K. 1993. Market orientation: Antecedents and consequences. Journal of Marketing, 57(3): 53-70.

Johanson, J., \& Vahlne, J.-E. 1977. The internationalization process of the firm: A model of knowledge development and increasing foreign market commitments. Journal of International Business Studies, 8(1): 25-34.

Johanson, J., \& Vahlne, J. E. 2009. The Uppsala internationalization process model revisited: From liability of foreignness to liability of outsidership. Journal of International Business Studies, 40(9): 1411-1431.

Jones, M. V., \& Coviello, N. E. 2005. Internationalisation: Conceptualising an entrepreneurial process of behaviour in time. Journal of International Business Studies, 36(3): 284-303.

Katsikeas, C. S. 1996. Ongoing export motivation: Differences between regular and sporadic exporters. International Marketing Review, 13(2): 4-19.

Katsikeas, C. S., Leonidou, L. C., \& Morgan, N. A. 2000. Firmlevel export performance assessment: Review, evaluation, and development. Journal of the Academy of Marketing Science, 28(4): 493-511.

Katsikeas, C. S., Morgan, N. A., Leonidou, L. C., \& Hult, G. T. M. 2016. Assessing performance outcomes in marketing. Journal of Marketing, 80(March): 1-20.

Katsikeas, C. S., Samiee, S., \& Theodosiou, M. 2006. Strategy fit and performance consequences of international marketing standardization. Strategic Management Journal, 27(9): 867-890.

Katsikeas, C. S., Skarmeas, D., \& Bello, D. 2009. Building successful trust-based international exchange relationships. Journal of International Business Studies, 40(1): 132-155.

Klein, J. G., Ettenson, R., \& Morris, M. D. 1998. The animosity model of foreign product purchase: An empirical test in the People's Republic of China. Journal of Marketing, 62(1): 89-100.

Knight, G. A., \& Cavusgil, S. T. 2004. Innovation, organizational capabilities, and the born-global firm. Journal of International Business Studies, 35(2): 124-141.

Kogut, B., \& Singh, H. 1988. The effect of national culture on the choice of entry mode. Journal of International Business Studies, 19(3): 411-432.
Kogut, B., \& Zander, U. 1992. Knowledge of the firm, combinative capabilities, and the replication of technology. Organization Science, 3(3): 383-397.

Kohli, A. K., \& Jaworski, B. J. 1990. Market orientation: The construct, research propositions, and managerial implications. Journal of Marketing, 54(2): 1-18.

Kotabe, M. 2001. Contemporary research trends in international marketing: The 1990s. In A. M. Rugman, \& T. L. Brewer (Eds.), Oxford handbook of international business: 457-502. Oxford: Oxford University Press.

Kotabe, M., \& Murray, J. Y. 1990. Linking product and process innovations and modes of international sourcing in global competition: A case of foreign multinational firms. Journal of International Business Studies, 21(3): 383-408.

Kotabe, M., Srinivasan, S. S., \& Aulakh, P. S. 2002. Multinationality and firm performance: The moderating role of R\&D and marketing capabilities. Journal of International Business Studies, 33(1): 79-97.

Leonidou, L. C., \& Katsikeas, C. S. 1996. The export development process: An integrative review of empirical models. Journal of International Business Studies, 27(3): 517-551.

Leonidou, L. C., Katsikeas, C. S., \& Samiee, S. 2002. Marketing strategy determinants of export performance: A meta-analysis. Journal of Business Research, 53(1): 51-67.

Leonidou, L. C., Katsikeas, C. S., Samiee, S., \& Aykol, B. 2017. International marketing research: A state-of-the-art review and the way forward. In L. C. Leonidou, C. S. Katsikeas, S. Samiee, $\&$ B. Aykol (Eds.), Advances in global marketing: A research anthology: 3-33. Cham: Springer.

Leonidou, L., Samiee, S., Aykol, B., \& Talias, M. 2014. Antecedents and outcomes of exporter-importer relationship quality: Synthesis, meta-analysis, and directions. Journal of International Marketing, 22(2): 21-46.

Levitt, T. 2006. What business are you in? Classic advice from Theodore Levitt. Harvard Business Review, 84(10): 126-137.

Lovett, S., Simmons, L. C., \& Kali, R. 1999. Guanxi versus the market: Ethics and efficiency. Journal of International Business Studies, 30(2): 231-247.

Lu, I. R. R., Heslop, L. A., Thomas, D. R., \& Kwan, E. 2016. An examination of the status and evolution of country image research. International Marketing Review, 33(6): 825-850.

March, J. G. 1991. Exploration and exploitation in organizational learning. Organization Science, 2(1): 71-87.

McAlexander, J. H., Schouten, J. W., \& Koenig, H. F. 2002. Building brand community. Journal of Marketing, 66(1): 38-54.

McKenna, R. 1991. Marketing is everything. Harvard Business Review, 69(1): 65-79.

Moorman, C., \& Day, G. S. 2016. Organizing for marketing excellence. Journal of Marketing, 80(6): 6-35.

Morgan, R. M., \& Hunt, S. D. 1994. The commitment-trust theory of relationship marketing. Journal of Marketing, 58(3): 20-38.

MSI 2020. Marketing Science Institute research priorities: 2020-2022. Marketing Science Institute.

Mullen, M. R. 1995. Diagnosing measurement equivalence in cross-national research. Journal of International Business Studies, 26(3): 573-596.

Narver, J. C., \& Slater, S. F. 1990. The effect of a market orientation on business profitability. Journal of Marketing, 54(4): 20-35.

Nelson, R. R., \& Winter, S. G. 1982. An evolutionary theory of economic change. Cambridge, MA: Harvard University Press.

Palmatier, R. W. 2008. Interfirm relational drivers of customer value. Journal of Marketing, 72(4): 76-89.

Papadopoulos, N., el Banna, A., Murphy, S. A., \& Rojas-Méndez, J. I. 2011. Place brands and brand-place associations: The role of 'place' in international marketing. In S. C. Jain, \& D. A. Griffith (Eds.), Handbook of research in international marketing: 88-113. Cheltenham: Edward Elgar. 
Peng, M. W. 2004. Identifying the big question in international business research. Journal of International Business Studies, 35(2): 99-108.

Penrose, E. T. 1959. The theory of the growth of the firm. New York: Wiley.

Peterson, R. A., \& Jolibert, A. J. 1995. A meta-analysis of countryof-origin effects. Journal of International Business Studies, 26(4): 883-900.

Pfeffer, J., \& Salancik, G. R. 1978. The external control of organizations: A resource dependence perspective. New York: Harper \& Row.

Porter, M. E. 1980. Competitive strategy: Techniques for analyzing industries and competitors. New York: Free Press.

Porter, M. E. 1985. Competitive advantage: Creating and sustaining superior performance. New York: Free Press.

Porter, M. E. 1990. Competitive advantage of nations. New York: Free Press.

Prahalad, C. K., \& Ramaswamy, V. 2004. The future of competition: Co-creating unique value with customers. Cambridge, MA: Harvard Business Press.

Ricks, D. A., \& Samiee, S. 1974. Leasing: It may be right abroad even when it is not at home. Journal of International Business Studies, 5(2): 87-90.

Robson, M. J., Katsikeas, C. S., Schlegelmilch, B. B., \& Pramböck, B. 2019. Alliance capabilities, interpartner attributes, and performance outcomes in international strategic alliances. Journal of World Business, 54(2): 137-152.

Roth, M. S., \& Romeo, J. B. 1992. Matching product category and country image perceptions: A framework for managing country-of-origin effects. Journal of International Business Studies, 23(3): 477-497.

Rugman, A. M., \& Verbeke, A. 2008. A new perspective on the regional and global strategies of multinational services firms. Management International Review, 48(4): 397-411.

Samiee, S. 1994. Customer evaluation of products in a global market. Journal of International Business Studies, 25(3): 579-604.

Samiee, S., \& Chabowski, B. R. 2012. Knowledge structure in international marketing: A multi-method bibliometric analysis. Journal of the Academy of Marketing Science, 40(2): 364-386.

Samiee, S. \& Chabowski, B. R. 2021. Knowledge structure in product- and brand origin-related research. Journal of the Academy of Marketing Science. https://doi.org/10.1007/ s11747-020-00767-7.

Samiee, S., Chabowski, B. R., \& Hult, G. T. M. 2015. International relationship marketing: Intellectual foundations and avenues for further research. Journal of International Marketing, 23(4): 1-21.

Samiee, S., \& Walters, P. G. P. 1991. Segmenting corporate exporting activities: Sporadic versus regular exporters. Journal of the Academy of Marketing Science, 19(2): 93-104.

Schooler, R. D. 1965. Product bias in the Central American Common Market. Journal of Marketing Research, 2(3): 394-397.

Sharma, P. 2015. Consumer ethnocentrism: Reconceptualization and cross-cultural validation. Journal of International Business Studies, 46(3): 381-389.

Skarmeas, D., Katsikeas, C. S., \& Schlegelmilch, B. B. 2002. Drivers of commitment and its impact on performance in cross-cultural buyer-seller relationships: The importer's perspective. Journal of International Business Studies, 33(4): 757-783.

Steenkamp, J.-B.E.M., Batra, R., \& Alden, D. L. 2003. How perceived brand globalness creates brand value. Journal of International Business Studies, 34(1): 53-65.

Swamidass, P. M., \& Kotabe, M. 1993. Component sourcing strategies of multinationals: An empirical study of European and Japanese multinationals. Journal of International Business Studies, 24(1): 81-99.

Takeuchi, H., \& Porter, M. E. 1986. Three roles of international marketing in global strategies. In M. E. Porter (Ed.),
Competition in Global Industries: 111-146. Cambridge, MA: Harvard Business School Press.

Teece, D. J., Pisano, G., \& Shuen, A. 1997. Dynamic capabilities and strategic management. Strategic Management Journal, 18(7): 509-533.

Tihanyi, L., Griffith, D. A., \& Russell, C. J. 2005. The effect of cultural distance on entry mode choice, international diversification, and MNE performance: A meta-analysis. Journal of International Business Studies, 36(3): 270-283.

Trout, J. 2006. Peter Drucker on marketing. Forbes, July 3. Retrieved August 22, 2020, from https://www.forbes.com/ 2006/06/30/jack-trout-on-marketing-cx_jt_0703drucker. html\#1 ef6ac0a555c

Ulgado, F. M. 2002. Country-of-origin effects on e-commerce. Journal of American Academy of Business, 2(1): 250-253.

Verlegh, P. W. J., \& Steenkamp, J.-B.E.M. 1999. A review and meta-analysis of country-of-origin research. Journal of Economic Psychology, 20(5): 521-546.

Watson, G. F., IV., Weaven, S., Perkins, H., Sardana, D., \& Palmatier, R. W. 2018. International market entry strategies: Relational, digital, and hybrid approaches. Journal of International Marketing, 26(1): 30-60.

Webster, F. E., Jr. 2009. Marketing IS management: The wisdom of Peter Drucker. Journal of the Academy of Marketing Science, 37(1): 20-27.

Wernerfelt, B. 1984. A resource-based view of the firm. Strategic Management Journal, 5(2): 171-180.

Wiedersheim-Paul, F., Welch, L., \& Olson, H. 1978. Pre-export activity: The first steps in internationalization. Journal of International Business Studies, 9(1): 47-58.

Williamson, O. E. 1975. Markets and hierarchies, analysis and antitrust implications: A study in the economics of internal organization. New York: Free Press.

Williamson, O. E. 1985. The economic institutions of capitalism: Firms, markets, and relational contracting. New York: Free Press.

Xie, Z., \& Li, J. 2018. Exporting and innovating among emerging market firms: The moderating role of institutional development. Journal of International Business Studies, 49(2): 222-245.

\section{ABOUT THE AUTHORS}

Saeed Samiee is the Collins Professor of Marketing and International Business at the University of Tulsa. He contributes to scholarly journals in marketing and international business with a focus on international marketing strategy, export marketing, and international digital marketing. He is editor for the Journal of International Business Studies and serves as associate editor for Decision Sciences Journal. He is the 2017 recipient of the Significant Contributions to Global Marketing Award from the American Marketing Association Global Marketing Special Interest Group, a Distinguished Fellow of the Academy of Marketing Science, and a Fellow of the Academy of International Business.

Constantine S. Katsikeas is the Arnold Ziff Research Chair and Professor of Marketing and International Management, and the Founder and Director of the Global and Strategic Marketing Research Center at the University of Leeds. His interests are global marketing and exporting, sales 
management, cross-border relationships and strategic alliances. He is an AIB Fellow and currently serves as Editor for Journal of International Business Studies and Area Editor for Journal of the Academy of Marketing Science.

G. Tomas M. Hult is professor at Michigan State University and visiting professor at Uppsala University, a member of the expert network of the
World Economic Forum, involved with UNCTAD's World Investment Forum, and a part of the leadership team at the American Customer Satisfaction Index (ACSI). His research interests are international marketing, marketing strategy, customer satisfaction, supply chain management, and international business.

Publisher's Note Springer Nature remains neutral with regard to jurisdictional claims in published maps and institutional affiliations.

Accepted by Alain Verbeke, Editor-in-Chief, 29 March 2021. This article has been with the authors for one revision and was single-blind reviewed. 